\title{
Pyosalpinx and Hydrosalpinx in Virginal Adolescents: Report of Two Cases
}

\author{
S Moralioğlu, IO Özen, B Demiroğullari, AC Başaklar
}

\begin{abstract}
Pyosalpinx and hydrosalpinx are conditions mainly seen in adult women, but also among sexually active adolescents and can bring added hazard to fertility. However, these conditions are very rare in childhood, as well as in adolescent girls who are not sexually active.

We are presenting two rare cases of young girls in early puberty with hydrosalpinx and pyosalpinx. Both girls had a history of abdomino-pelvic surgery in childhood for congenital bowel anomalies and fecal incontinence. Such cases are good reminders that girls with known abdominopelvic anomalies and surgical procedures in childhood need long term follow-up, in particular when entering puberty and maturation. The two cases show how fallopian tubes can be indirectly affected and present in adolescence with serious problems needing surgical procedures and potentially threatening future reproductive system performances.
\end{abstract}

Keywords: Adolescence, hydrosalpinx, pyosalpinx

\section{Piosálpinx e Hidrosálpinx en Adolescentes Vírgenes: Reporte de Dos Casos} S Moralioğlu, IO Özen, B Demiroğullari, AC Başaklar

\begin{abstract}
RESUMEN
El piosálpinx y el hidrosálpinx son condiciones vistas principalmente en mujeres adultas, pero también entre las adolescentes sexualmente activas, y pueden acarrear riesgos a la fertilidad. Sin embargo, estas condiciones son muy raras en la infancia, así como en las niñas adolescentes que no están sexualmente activas. Presentamos dos casos raros de jovencitas en la pubertad temprana con hidrosálpinx y piosálpinx. Ambas adolescentes tenían antecedentes de cirugía abdominopélvica en la infancia a causa de anomalías congénitas del intestino e incontinencia fecal. Tales casos son buenos recordatorios de que las muchachas con anomalías y procedimientos quirúrgicos abdominopélvicos en la niñez, necesitan seguimiento a largo plazo, en particular al entrar en la pubertad y la madurez. Los dos casos muestran cómo las trompas de Falopio pueden ser indirectamente afectadas, y presentarse en la adolescencia con graves problemas que necesitan procedimientos quirúrgicos y operaciones que constituyen una amenaza potencial al sistema reproductor.
\end{abstract}

Palabras clave: Adolescencia, hidrosálpinx, piosálpinx

West Indian Med J 2013; 62 (3): 257

\section{INTRODUCTION}

Formation of a pyo/hydrosalpinx, derived from the Greek words meaning a fallopian tube filled with pus or fluid, is the result of a chronic pathological condition of the fallopian tube when the fimbrial end of the tube is occluded and the distal part distended (1). They are very rare gynaecologic

From: Gazi University Medical Faculty, Department of Pediatric Surgery, Ankara, Turkey.

Correspondence: Dr S Moralioğlu, Arakiyeci Haci Mehmet Mah. Op.Dr.Burhanettin Üstünel Cad. No:10, 34668 Üsküdar, İstanbul, Turkey.

E-mail: serdarmoralioglu@gmail.com problems during adolescence, especially in virgin girls. However, pelvic infection/inflammation, pelvic surgery, endometriosis or anatomic abnormalities may lead to serious tubal problems.

Here, two adolescent girls having pyo- and hydrosalpinx are reported and predisposing factors are discussed.

\section{CASE REPORTS}

Case 1: A 13-year old patient was admitted with severe abdominal pain. Physical examination revealed tenderness, abdominal guarding and rebound in the right lower quadrant of abdomen. She had a hockey stick incision scar in the left 
lower quadrant of the abdomen. She was a virgin and had normal vital functions. She had a history of abdominoperineal pull-through operation at 10 months of age because of long segment Hirschsprung disease (HD) and had fecal incontinence caused by a short colon. She had menarche at age 12 years and regular periods, as well as pubertal development.

Complete blood count, tumour markers and urine tests were within normal limits. Abdominopelvic ultrasound revealed a cyst measuring $10 \times 6.5 \mathrm{~cm}$ in size filled with clear fluid and septations in the right adnexal region. Similarly, pelvic computed tomography (CT) scan showed a septated cyst nearly $10 \times 6 \times 7 \mathrm{~cm}$ in size (Fig. 1). During explorative

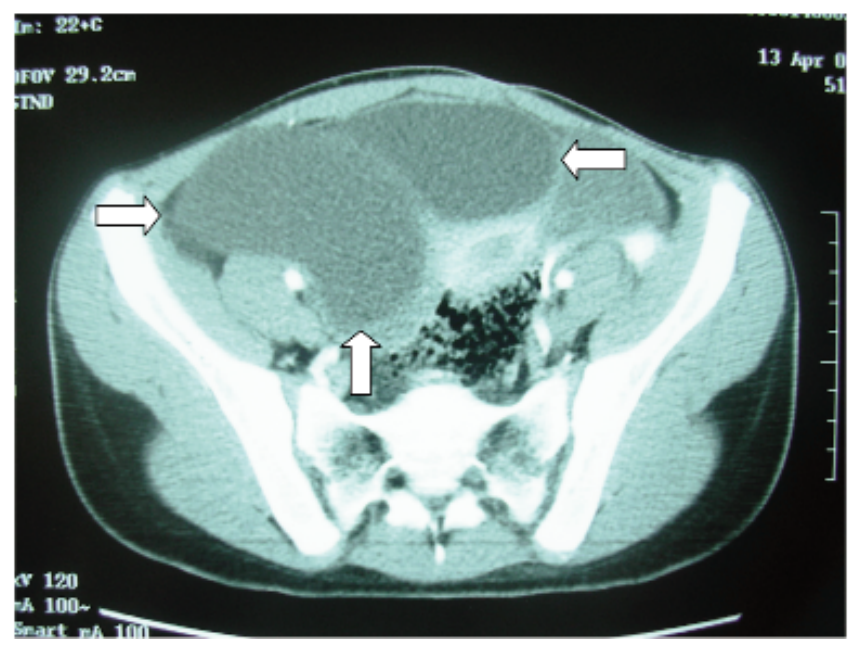

Fig. 1: Computed tomography (CT) scan showed a right adnexal septated cyst (arrows) measuring $10 \times 6 \times 7 \mathrm{~cm}$.

laparotomy, hydrosalpinx was found in the right fallopian tube and right salpingectomy was carried out (Fig. 2). The patient was discharged uneventfully. The histopathology result confirmed hydrosalpinx.

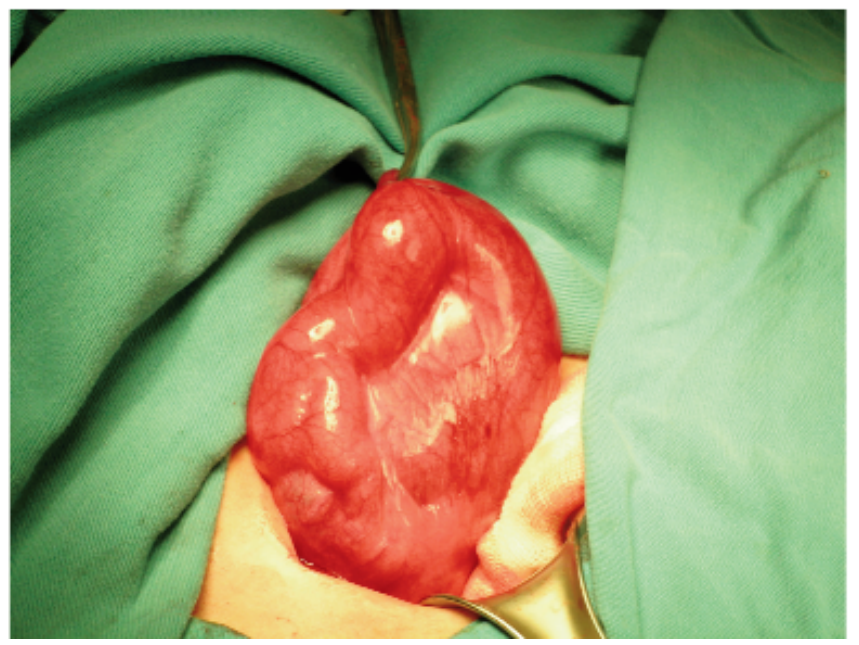

Fig. 2: Intraoperative view of the right-sided hydrosalpinx.
One year after the operation, during routine ultrasound control, a cystic dilatation was seen in the left adnexa $(5 \mathrm{~cm}$ in diameter) and hydrosalpinx formation was confirmed by pelvic magnetic resonance imaging (MRI). Since she had normal menstrual cycle and no abdominal complaints, no further intervention was performed. She is still under followup and receiving loperamide hydrochloride (HCL) and a stool thickener, motility reducer diet for prevention of diarrhea and fecal incontinence.

Case 2: A 14-year old patient was admitted with abdominal pain, vomiting and fever $\left(39^{\circ} \mathrm{C}\right)$. Physical examination revealed abdominal tenderness with guarding and rebound in the right lower quadrant of abdomen. In the past, she had a perineal pull-through procedure because of rectovestibular fistula with anal atresia when she was two years of age, and she had sigmoid resection for severe constipation with fecal soiling when she was 11 years old. Her hymen was crescentic and her vagina had lost elasticity and narrowed due to previous perineal pull-through operation. In addition, she had uterus bicornis unicollis and septate vagina, and irregular menstrual cycle since menarche at 13 years of age.

Her laboratory tests were normal except leukocyte count $\left(13900 / \mathrm{mm}^{3}\right)$. A thick-walled cystic lesion $(10.5 \mathrm{~cm} \mathrm{x}$ $7.5 \mathrm{~cm}$ ) containing internal septations was revealed by ultrasound in the right adnexal region. Computed tomography scan was compatible with ultrasound findings (Fig. 3). A

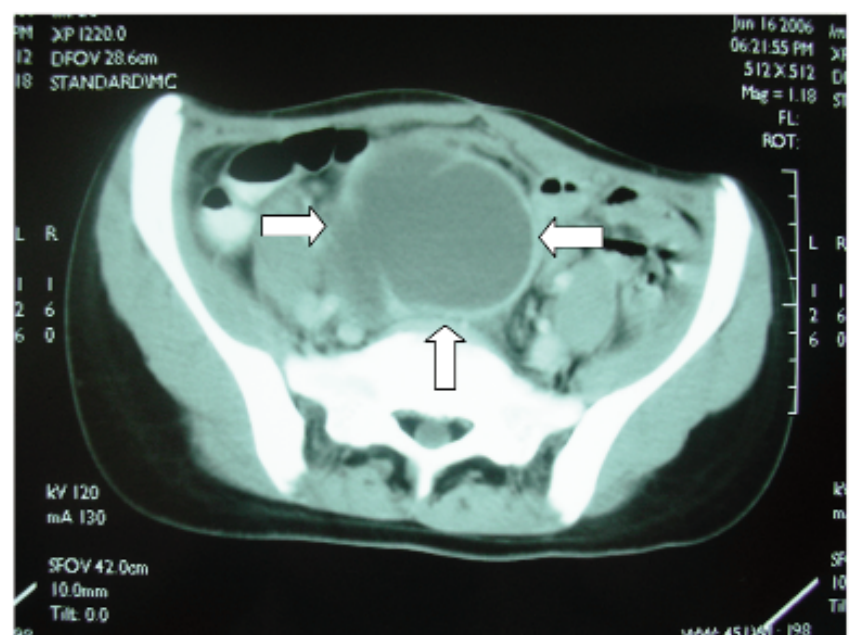

Fig. 3: Computed tomography (CT) scan showed a right adnexal septated cyst (arrows) measuring $11 \times 10 \times 8 \mathrm{~cm}$.

right-sided gangrenous pyosalpinx was found at explorative laparotomy and salpingectomy, pelvic cavity lavage and drainage of the pouch of Douglas were performed (Fig. 4). Escherichia coli was detected in the culture obtained from the cyst. Ceftriaxone and metronidazole treatment were started before the operation and continued during the postoperative period. The patient had an uneventfully course. Histopathological evaluation showed pyosalpinx. 


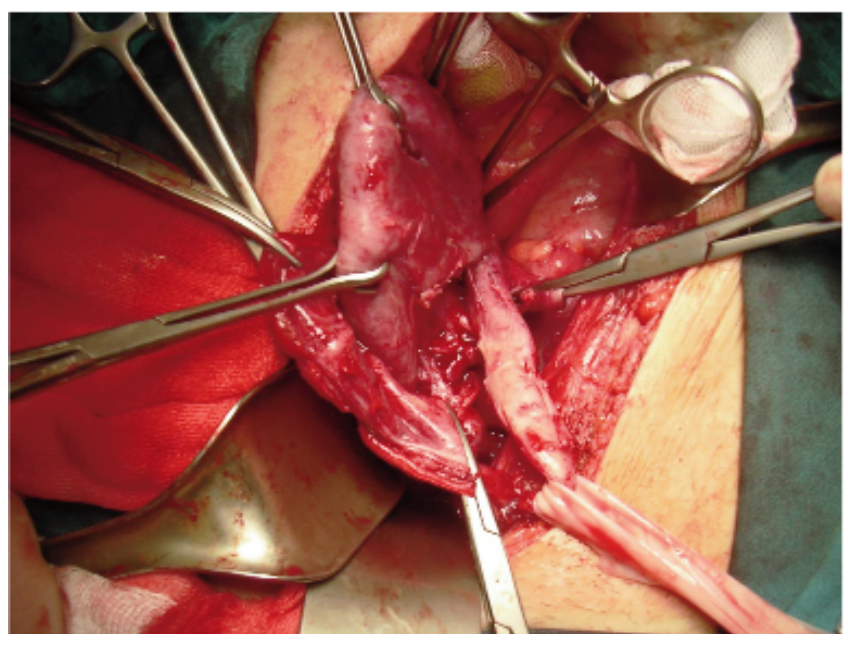

Fig. 4: Intraoperative view of the right-sided pyosalpinx.

\section{DISCUSSION}

The frequency of pyo/hydrosalpinx in adolescent virgin patients is very rare and, therefore, there may be difficulty in establishing the diagnosis (2). However, pelvic inflammatory disease, intra-abdominal infection or surgery can result in pyo/hydrosalpinx. Both of our cases had predisposing factors and were candidates for tubal problems. Anatomic anomalies leading to gynaecologic complications have been reported, previously (3). Girls with genital anomalies, such as double or septate vagina, vaginal atresia or stenosis, uterus didelphys and uterus bicornis unicollis may have hydrosalpinx, pyosalpinx, haematocolpos, haematometrocolpos, tubo-ovarian abscess and peritonitis. Fecal incontinence was thought to contribute to pyosalpinx in Case 2 who had a genital abnormality.

The cause of hydrosalpinx in Case 1 might be only due to surgery in view of normal anal and genital anatomy though she had fecal incontinence. Bilateral non-inflammatory hydrosalpinx in adolescents who were treated by pullthrough procedure for Hirschsprung's disease has been reported as a postoperative complication (4).

Laparoscopic approach is a good option for the treatment of distended fallopian tube. Aspiration in such cases is not the treatment of choice and moreover, may cause complications $(2,5)$. However, because of previous sur- geries, we preferred the open technique in these cases. The hydrosalpinx in Case 1 was so big and tubal anatomy was extremely distorted, that a simple drainage would have been insufficient and at risk for a torsion in future, hence it was resected. However, after the operation, she developed hydrosalpinx on the contralateral side as has been previously reported in the literature (4). As she was asymptomatic, she was kept under close follow-up. Pyosalpinx, especially the gangrenous type, carries a risk of perforation (6), therefore, it was resected in Case 2. Different surgical techniques have been performed for hydrosalpinges. Unquestionably, the debate on the use of salpingectomy compared with a more conservative approach to hydrosalpinges will continue.

Generally, a diagnosis of a pelvic mass is made by ultrasound. Recently, CT scan results have been found to correlate with histopathological findings in the patients who had tubo-ovarian abscesses (7). In our cases, ultrasound and CT were used for diagnosis, but MRI was preferred during the follow-up period because of the harmful effects of X-ray.

The differential diagnosis in adolescent girls with lower abdominal pain includes appendicitis, diverticulitis, urinary tract infection, peritonitis and others. However, one must keep in mind the probability of fallopian tube problems in patients with previous pelvic surgery and/or congenital genitourinary anomaly.

\section{REFERENCES}

1. Mansour RT, Aboulghar MA, Serour GI. Controversies in the surgical management of hydrosalpinx. Curr Opin Obstet Gynecol 2000; 12: 297-301.

2. Hornemann A, Koschitzky H, Bohlmann MK, Hornung D, Diedrich K, Taffazoli K. Isolated pyosalpinx in a 13-year-old virgin. Fertil Steril 2009; 91: 2732.e9-10.

3. Mollitt DL, Schullinger JN, Santulli TV, Hensle TW. Complications at menarche of urogenital sinus with associated anorectal malformations. J Pediatr Surg 1981; 16: 349-52.

4. Merlini L, Anooshiravani M, Peiry B, La Scala G, Hanquinet S. Bilateral hydrosalpinx in adolescent girls with Hirschsprung's disease association of two rare conditions. AJR 2008; 190: 278-82.

5. Pinkert M, Klein Z, Tepper R, Beyth Y. Hydrosalpinx with adnexal torsion in an adolescent virgin patient - a diagnostic dilemma. Case report and review of the literature. J Pediatr Adolesc Gynecol 2006; 19: 297-9.

6. Habek D, Vranko Nagy N, Sklebar I, Grabovac S, Cerkez Habek J. Rupture of coliform pyosalpinx in a nine-year old girl. Zentralbl Gynakol 2002; 124: 220-2.

7. Jeong WK, Kim Y, Song SY. Tubo-ovarian abscess: CT and pathological correlation. Clinical Imaging 2007; 31: 414-8. 